S. Calkin

\title{
Transnational Abortion Pill Flows and the Political Geography of Abortion in
}

\section{Ireland}

\begin{abstract}
"She had heard of a Netherlands-based NGO that posts abortion pills to women all over the world; she looked it up, then filled in its medical consultation form at home, on her laptop... Emily paid €90 by PayPal - 'It's not cheap, but it is a lot less than travelling for an abortion' - and arranged to have the drugs delivered to the Antrim depot of Parcel Motel, the north-south delivery service, and from there to a collection kiosk near her home. Although Parcel Motel's website says it cannot accept “controlled substances or illegal drugs", Emily's parcel made it to Dublin about a fortnight after she ordered it. 'I was sure someone knows, that there were going to be guards. I was certain something was going to happen. But it didn't."' (Holland 2015)
\end{abstract}

The above account was published in the Irish Times in 2015 under the headline "Emily's Story: An Illegal Abortion in Ireland." It explains, through one woman's experience, how growing numbers of women in the Republic of Ireland were accessing abortion pills inside a state whose constitution contained a near total-ban on abortion and whose criminal laws imposed a possible 14-year prison sentence for the use of abortion pills for self-managed abortion. The story also illustrates the infrastructures through which abortion pills circulate as they cross political borders. The best available data, although incomplete, indicate that by 2017 , between three and six Irish women requested abortion pills every day using the same technologies and networks that Emily did (Aiken et al. 2017).

Pharmaceutical abortion pills are also known as Early Medical Abortion and by the acronym EMA, which I use throughout this article. ${ }^{1}$ The transformative impact of medication abortion pills worldwide has been well established: the public health literature demonstrates that

\footnotetext{
${ }^{1}$ The drug usually referred to as the 'abortion pill' actually comprises two drugs with different histories and geographies: misoprostol and mifepristone. The WHO protocol for medication abortion calls for a combination of mifepristone and misoprostol, but misoprostol-only protocols dominate because misoprostol is often sold in pharmacies for the treatment of ulcers, even in countries where abortion is highly restricted (de Zordo 2016; Drovetta 2015). Unlike misoprostol, mifepristone was developed specifically for the medical termination of pregnancy so states with very restrictive abortion laws often do not license it at all (Gynuity 2017). Studies show that misoprostol-only regimens are around $85 \%$ effective, compared to an effectiveness rate of greater than $95 \%$ for combination mifepristone and misoprostol (Blumenthal et al. 2009).
} 


\section{S. Calkin}

growing access to abortion pills has contributed to a worldwide decline in deaths from illegal and unsafe abortions (Barot 2018; Ganatra et al. 2017). The availability of abortion pills depends on the national legal context for any form of abortion, surgical or pharmaceutical: some countries where abortion is banned also tightly restrict access to any medications with abortifacient effects, while others tolerate informal markets in abortion pills like misoprostol (de Zordo 2016; Jelinska and Yanow 2018; Drovetta 2015). Where abortion is legally available, EMA is generally licensed but restricted to prescription by doctors inside designated clinical spaces (Clarke and Montini 1993; Joffe and Weitz 2003; Sheldon 2014; Baird 2015; Campbell 2018). Feminist scholarship in this area has illustrated the varied socio-technical framings of EMA, contested by pro-choice and anti-abortion groups, and the national regulatory frameworks for it. However, the dimension of EMA that is least explored in the literature is also the most significant for broader debates about the changing relationship between women, states, and reproduction: its portability and transgressive cross-border circulations. If small, discrete, and easily smuggled abortion pills can be moved across political borders and into states where abortion is prohibited, might this mean that states are unable to enforce restrictive abortion laws?

In order to explore this question, in this article I bring EMA into conversation with Political Geography and International Relations literatures on materiality (Salter et al. 2015, 2016). This literature grapples with the way that sovereignty, territoriality, and borders are constructed and made by states, as well as the ways that material objects challenge or transform performances of stateness. Understanding changing patterns of abortion access today requires an engagement with debates about the nature of the state and its borders, because abortion pills and the transnational circuits they follow exceed the state's existing framework for the domestic governance of abortion (Calkin 2019a). In its encounter with abortion pills, we see that the state today misunderstands what kind of thing abortion is. If abortion is a medical procedure, confined to a clinic, perhaps it can be obstructed through laws that eliminate the clinical space and medical capacity to offer it. If abortion is a more ephemeral flow of cheap pharmaceuticals that travel through existing digital platforms, postal infrastructure, and border checkpoints, then conventional state frameworks to prohibit abortion may become obsolete. Examining the materiality of EMA makes us think differently about abortion and its regulation because EMA exhibits what Melissa White - writing about viruses - calls an "unruly mobility" that allows this material to "scramble" borders and political scales, prompting a corresponding scramble for the control of its circulation (White 2015, 142-3). 


\section{S. Calkin}

Ireland is the empirical context in which I examine EMA's "unruly mobility" and its encounter with the state. As Emily's story in the Irish Times shows, abortion access in Ireland was characterized by a contradictory mix of legal prohibition and practical toleration, as abortion pills became increasingly accessible there in the ten years before the 2018 referendum that repealed its constitutional ban. I argue that the Irish state's response to EMA was predominantly shaped by a fragmented understanding of the complex mobilities and territorial significance of abortion pills. When state agencies and actors were confronted with a crossborder influx of abortion pills, their actions (and calculated inaction) to manage these pills were shaped through analogies to familiar cross-border flows for which they had established responses. These responses, while frequently unsuccessful at blocking the inflow of pills, nonetheless sought to make public political claims about the integrity of its borders and the power of the sovereign state to regulate abortion inside its territory.

The article proceeds as follows: first, I situate abortion pills inside debates about the fluctuating spatiality of the state system, in order to show how the study of illicit flows in drugs and pharmaceuticals can help us understand abortion access today. I also adapt a set of methodological tools from Bourne's (2011) study of cocaine to examine the materiality of illicit flows across state borders. Second, I map out the geography of Ireland's $8^{\text {th }}$ amendment abortion ban to demonstrate how the state erected a moral-territorial border between Ireland and England, where thousands travelled for abortion. The influx of abortion pills disrupted the spatial arrangement of abortion upon which Ireland's ban rested. In the three sections that follow, I examine how different Irish state agencies understood the growing demand for and supply of abortion pills inside the state: the customs agency/medicines regulator, public health actors, and the legislature imposed their own policy frameworks onto EMA and sought to respond to illegal abortion pills in ways that would reassert state territoriality and control. I conclude by reflecting on what this analysis means for Ireland after the repeal of the $8^{\text {th }}$ amendment and the introduction of a new abortion law. The data for this article was collected through interviews with activists from Irish and Northern Irish pro-choice organizations, interviews with European telemedicine organizations that distribute EMA, analysis of Irish 


\section{S. Calkin}

government documents, and analysis of legislative debates in the Irish Houses of the Oireachtas (the legislature). ${ }^{2}$

\section{Materiality, Technology, and Unruly Mobilities}

Picture a small box of abortion pills: smuggled across a border in a suitcase, or shipped through the post to an intermediary, re-packaged, and posted onwards in a plain envelope. The forces that propel its supply and demand, the logistics that shape its journey, and the political impact of its medical effect all speak to major debates about states and their territoriality today. In particular, they speak to the way that the materiality and movement of objects in and between political territories impact on power, sovereignty, and the state system. Sovereignty and 'stateness' are daily, prosaic practices that enrol material objects: the assertion of 'stateness' takes place at diverse sites, performed through the repetitive layering of actions, the use of objects and technologies to communicate territorial control, and the repetition of spatial practices to assert the state's territoriality (Painter 2006). Territory is "laboriously generated through" countless mundane practices, whether through "the maintenance of border crossings, the decisions of immigration officials, the issuing of visas" or "the policing of smuggling" (Ibid, 765). Nonetheless, the gulf between the state's performance of sovereignty and its actual ability to act as a sovereign with full territorial control is ever present. Materiality is implicated in the state's crisis of authority, because the connections that objects can catalyse exceed the territorial forms that structure the international system (Salter 2015, 2016; Braun and Whatmore 2010).

Political Geography has extensively documented how the spatiality of state power is in flux. Pipelines of goods in supply chains re-arrange state power and reshape territorial boundaries; digital technologies extend the sites and subjects of border surveillance; contemporary modes of political and economic governance increasingly produce a mismatch between a state's territory and its authority (Cowen 2014; Sassen 2013; Amoore 2006). This spatial rearrangement signifies new forms of state power as well as new vulnerabilities: states today

\footnotetext{
2 The activities and infrastructures of pill networks inside Ireland and Northern Ireland are generally regarded as illegal and have been the subjects of police and prosecutorial action, discussed below. In order to prevent exposing interviewees or pill networks to legal risk, any specific logistical details about pill networks that appear in this article have been previously disclosed in the national news media, parliamentary testimony, or other academic scholarship.
} 


\section{S. Calkin}

see themselves as fighting a losing battle against illegal flows in drugs, arms, people, intellectual property, money, nuclear material, and disease that travel through the same social and technical infrastructures that facilitate commerce in the global economy (van Schendel and Abraham 2005). If the most basic function of the state is to secure control over the monopoly of violence in a given territory, the inability to control access to that territory - by people, goods, and digital flows - calls the legitimacy of state power and the state form into question. States tend to perceive these cross-border flows as national security threats, and respond through efforts to securitize supply chains, digital financial flows, and human mobility, by drawing new boundaries around spaces and populations (Amoore 2006; Bourne 2011).

The popular discourse around globalization tends to suggest a shadowy, disembodied set of networks that permeate borders, although these transnational flows are anchored in existing infrastructures and social relations (van Schendel 2005, 46). It would be misleading to contrast territorial states and their borders with de-territorialized networks that attempt to cross them. States in fact "structure, condition, produce and enable" clandestine border crossings, not least because it is often political choices made within the state which fuels demand for the import of illicit goods (Ibid. 59-60; Taylor et al. 2013). Material flows not only move across territorial borders: they also move across categories of licit/ illicit and legal/ illegal, because these designations largely depend on moral and customary judgments that shift across time and place (Gregson and Crang 2017). Materials that circulate across borders therefore navigate numerous conceptual distinctions, only some of which correspond to the territorial boundaries of states.

The task of studying illicit flows presents methodological difficulties, because they tend not to materialize as stable, visible entities that can be easily studied in their totality. Michael Bourne's study of cocaine flows offers a useful set of methodological tools for understanding transgressive materialities that cross boundaries of licit/ illicit (2015). Bourne examines cocaine as the focus of an international regime of trafficking, control and prohibition (Ibid, 328). In order to understand how cocaine functions as a lively material flow in the state system, Bourne maps the international geography of cocaine's production, movement, and consumption as it comes into tension with state-based efforts to prohibit its use or control its flow. Cocaine's illicit flows are made comprehensible and actionable to the state when they are "brought into categorical and logical proximity with other transnational flows" like international crime and terrorism (Ibid, 338-9). Things that are "unmappable for [their] fluidity" often come to be understood by governments through a "spatialized lexicon" that 


\section{S. Calkin}

maps them onto familiar flows (Bannister et al. 2015: 366). States seek to manage cocaine through regulatory distinctions that can travel across time and space, and therefore to govern it through existing practices of control. This analysis of cocaine offers a productive methodology for the study of other materials like abortion pills, whose unruly mobilities make them the target of numerous state interventions. These transnational flows do not occupy a single, stable position in the state system: their mobility and instability are central to their political effect. As such, governmental action to manage and control these flows is often fragmented between and across scales, enrolling a range of actors and practices.

\section{Irish Abortion Geographies}

Ireland's highly restrictive abortion regime - among the most conservative in Europe until 2018 - and its political geography make it an ideal site to explore the transnational circuits of abortion pills. Ireland banned abortion through its criminal code from 1922 and it established a constitutional abortion ban in 1983 when the $8^{\text {th }}$ amendment was adopted by referendum: this amendment committed the state to "vindicate" the "equal right to life" of the fetus (see de Londras and Enright 2018). Ireland's long history of prohibiting abortion means that abortion travel to England has been a feature of Irish life at least since the early $20^{\text {th }}$ century, accelerating after the passage of the 1967 Abortion Act in Britain (Rossiter 2009). Between 1983 and 2018 , an estimated 170,000 women travelled abroad from Ireland for abortion, most of them to England. Abortion travel became a formal part of Ireland's abortion regime when the freedom to travel for abortion was itself inserted into the constitution by referendum in 1992 (de Londras and Enright 2018).

Ireland's ability to maintain such a restrictive abortion regime depended on its political and cultural geography: for women who could travel freely and afford to pay, abortion was available after a short flight or ferry to England (Gilmartin and Kennedy 2018). Despite its near-total abortion ban, Ireland did not develop a culture of dangerous 'backstreet' abortions, partly as a result of the availability of safe abortion in neighbouring Britain (Rossiter 2009; Fletcher 2013). Anti-abortion conservatives could tout Ireland's status as an "abortion-free" territory and boast of its low maternal mortality rates because so many Irish women accessed reproductive healthcare in a different jurisdiction (Calkin 2019b; Fletcher 2013). Often drawing on nationalist narratives about Irish moral purity and British colonial violence, 


\section{S. Calkin}

defenders of the $8^{\text {th }}$ amendment regime portrayed the territorial boundary between Ireland and England as a moral boundary between cultures of life and death (Fletcher 1995, 2001; Smyth 2005; Browne and Nash 2020). Such narratives resonate in the longer history of Irish sexual politics, where conservative sexual and gender norms have been maintained through territorial strategies. Deviance from dominant moral codes was frequently "solved by emigration" by women with unwanted pregnancies, as well as LGBT people, interracial and cross-religious couples, and victims of sexual abuse (Luibhéid 2013, 37). So too was the need for abortion 'solved' by travel abroad - until abortion pills began to arrive in the country.

Abortion pills first entered Ireland in small numbers in 2006 when the Dutch organization Women on Web launched a telemedical abortion service that mailed pills to abortion-seekers after an online medical consultation (Aiken et al. 2017). During the following ten years, abortion access in Ireland was thoroughly transformed by pills. In 2001, eighteen women per day travelled abroad from Ireland for abortion; by 2016, this number had fallen by half to nine per day (Irish Family Planning Association 2018). Abortion travel numbers began to fall between 2002 and 2006, before abortion pills were accessible in Ireland, but after the establishment of a telemedicine abortion network in 2006, numbers of abortion-travellers declined sharply (Aiken 2017). Between 2010 and 2016, requests for abortion pills from women in Ireland and Northern Ireland ${ }^{3}$ tripled (Aiken et al. 2017). Data released by the two main telemedical abortion services suggest that by 2017, between three and six women per day in Ireland and Northern Ireland sought abortion pills online (Ibid.; Women Help Women 2018). ${ }^{4}$ While the precise quantity of abortion pills that entered Ireland for use in self-managed abortion cannot be determined, the decrease in people attending English clinics for abortions and the increase in reported requests made to telemedical services indicates a major shift in the geography of abortion access there.

From the mid-2010s onwards, abortion pills entered the public discourse through the deliberate efforts of activists who wanted to increase pressure on politicians to reform the abortion ban

\footnotetext{
${ }^{3}$ Some studies of abortion pill requests from the island of Ireland do not disaggregate the requests by country, so the available data combines figures from Ireland and Northern Ireland (see Aiken et al. 2017).

${ }^{4}$ Precise data on both abortion access strategies is incomplete: estimates of the total number of Irish abortion travellers are based on self-reporting of home addresses by patients in British abortion clinics, while estimated numbers of abortion pills entering Ireland can only be collected based on the numbers of impounded pills as reported by the Irish customs agency and numbers of pills requested/ shipped as reported by telemedical abortion services abroad.
} 


\section{S. Calkin}

and to "broaden the scope" of the public debate beyond the so-called 'hard cases' of pregnancies with fatal fetal anomaly or pregnancies that result from rape (Interview ROI-2). Activist staged events like the 2014 Abortion Pill Train where they went to Belfast to 'collect' abortion pills ${ }^{5}$ and then publicly ingested them upon returning to Dublin's Connolly Station; the police observed the protest without making any arrests or seizing pills, banners, or leaflets (Interview ROI-2). In 2016, a pro-choice TD associated with the activists displayed a packet of abortion pills on the floor of the Dáil: she set out to "de-mystify" the pills, explaining that they were safe to use and easily available through Women on Web (Interview ROI- $3^{6}$, see Dáil Debates 25/10/2016). During this period, activists in Ireland sought to raise the public visibility of abortion pills through protest actions, drawing on a longer history of Irish feminist activism on sexual and reproductive health rights, especially the 1970-80s protest actions against and clandestine subversion of the contraceptive ban (Cloatre and Enright 2017; Enright and Cloatre 2018; Connolly 2020).

Well before abortion law reform and before mainstream political debates about abortion liberalization, abortion pills were entering Ireland in substantial numbers to offer an illegal domestic mode of abortion access. Confronted with this challenge, how did the state understand and attempt to block the influx of illegal abortion pills? The state's response to EMA flows was slow, fragmented, and at times contradictory as it sought to bring EMA into 'logical proximity' with other analogous cross-border flows. In what follows, I use the conceptual tools of materiality and illicit flows, outlined in Section 2, to understand the significance of EMA for destabilizing Ireland's $8^{\text {th }}$ amendment abortion regime. I demonstrate how the Irish state sought to understand and control the mobility of EMA by treating it as analogous to three other issues: 1) Illegal pharmaceuticals; 2) Cross-border health threats; and 3) Digital flows of online goods.

\footnotetext{
${ }^{5}$ These activists on the Abortion Pill Train designed their protest to echo the 1971 Contraceptive Train, when activists bought legal condoms in Belfast and brought them to Dublin (see Connolly 2001, 2020). However, in 2014 abortion pills were illegal in both Northern Ireland and the Republic of Ireland. Northern Irish authorities actively investigated and prosecuted users of abortion pills. This Abortion Pill Train action provoked serious disagreement among pro-choice groups north and south, because some groups feared that it endangered women and activists by giving the false impression that abortion pills could be easily purchased over the counter in Northern Ireland (Interview, NI-2).

${ }^{6}$ Interview ROI-3: Member of the Dáil (lower house of the Irish legislature) and campaigner for repeal, interviewed November 2018.
} 


\section{S. Calkin}

\section{Abortion Pills as Pharmaceutical Contraband}

The movement of pharmaceuticals is governed by complex "logistic regimes" that link producer and consumer through a set of rules, regulations and discourses (Quet 2018). These regimes are structured by interactions between states who regulate the legality of drugs, national medicines regulators who determine the licenses and restrictions on prescription drugs, and private pharmaceutical companies who exert control over where, how, by whom, and for how much a drug can be obtained. The "erratic trajectories" of pharmaceutical logistics can create spaces for resistance, as with 'buyers clubs' networks that move pharmaceuticals between jurisdictions to circumvent prohibitive legal, medical, and price restrictions (Ibid, 83). In the case of EMA, the infrastructure used to move pills into Ireland connects activists across Europe and Ireland, pharmaceutical manufacturers in Asia, postal shipping and forwarding systems, and the physical infrastructure that links Ireland and Northern Ireland across the soft border.

From the first reported instance of abortion pills impounded at the border, the Irish customs and medicines agencies chose to treat imported abortion pills as analogous to the trade in online pharmaceuticals. This means that the products are considered illegal and are seized, but the individual consumers who purchase them are not usually subject to criminal sanctions. The decision to treat abortion pills like this represents a notable act of categorization by the state. Import of abortifacients was a violation of the 1979 Health (Family Planning Act) and the use of any "abortifacient" to end a pregnancy was criminalized by the 1861 Offences Against the Person Act $^{7}$ and the 2013 Protection of Life During Pregnancy Act, which specifically made it a crime punishable by a maximum 14-year prison sentence (de Londras and Enright 2018). Despite this, abortion pills have been treated as analogous to others pharmaceuticals whose import from foreign online pharmacies was illegal because of concerns over quality and safety (Sheldon 2018, 18). Other jurisdictions have treated possession and use of abortion pills as a crime, including Northern Ireland and Australia (Whitaker and Horgan 2016; Horgan 2019; Baird 2015). By contrast, the Irish medicines agency indicated it would only prosecute the commercial import and sale of abortion pills (Interview NI-1). ${ }^{8}$ The Irish compromise on this issue - to impound all shipments of abortion pills that customs could detect but not pursue

\footnotetext{
7 This law was inherited in the Irish criminal code from the period of British colonial rule. The 1861 Offences Against the Person act also governs abortion in parts of the UK today.

${ }^{8}$ Interview NI-1: Activist in a Northern Irish pro-choice organization, interviewed August 2018.
} 


\section{S. Calkin}

prosecutions of individuals who sought to obtain the pills - reflects a political ambivalence that has underpinned the state's approach to open violations of its abortion ban. Intercepting the flow of abortion pills through the post, and treating them as illicit pharmaceuticals, allowed the state to partially obstruct illegal abortions inside Ireland without having to resort to the politically disastrous prospect of prosecuting individual abortion-seekers or activists.

Women on Web began shipping EMA directly into Ireland in 2006. Initially, these packages made their way to their intended recipients, although they were being ordered by a very small number of people (Interview ROI-1). ${ }^{9}$ As part of their policy of impounding all pharmaceuticals purchased through mail-order services, the Irish customs agency began to seize incoming EMA shipments in 2008 (Ryan 2011; Interview ROI-1, EU-1). ${ }^{10}$ When telemedical networks like Women on Web sent registered packages of pills directly into Ireland, they were shipped from an Indian pharmaceutical manufacturer and thus carried the clear markings of pharmaceutical products purchased online. All goods from overseas pharmacies and prescription-only goods from Irish online retailers are prohibited (see HPRA 2017). Banned pharmaceuticals bought online are visually identified by their packaging and seized at customs checkpoints (HPRA quoted in Sheldon 2018, 18). People to whom the seized packages were addressed received notifications that their goods had been impounded, but no further action was taken against them (Interviews NI-1).

After it began seizing pills in substantial quantities at customs hubs around the country, the Health Products Regulatory Agency released periodic reports about its interventions and spoke to journalists about the annual number of shipments seized (see for example Ryan 2011). By 2009, interference by customs had made it so difficult to send pills that Women on Web stopped shipping directly to Ireland and developed an alternative route through Northern Ireland (Interview EU-1). Customs officials continued to seize abortion pills ordered through online pharmacies and issue intermittent reports on the numbers of pills impounded (Sheldon 2018). As part of Interpol's annual Operation Pangea (2008- present), Irish customs seized thousands of shipments of illegal medicines each year and held press conferences where seized abortion pills were displayed alongside steroids, diet pills, and sedatives (see, for example, Murphy

\footnotetext{
${ }^{9}$ Interview ROI-1: Activist in an Irish pro-choice organization, interviewed in July 2018

${ }^{10}$ Interview EU-1: Activist leading an Amsterdam-based telemedical abortion service, interviewed June 2018.
} 


\section{S. Calkin}

2016). These illegal medicines are regularly impounded at the regulatory border and confiscated, with few prosecutions or formal cautions issued (see HPRA 2016, 2017). ${ }^{11}$

Ireland's decision to seize all identifiable online pharmaceuticals - and thus all abortion pills bought from online pharmacies - transformed the logistical trajectory of EMA and reshaped its route through the island of Ireland ${ }^{12}$. Northern Ireland effectively became the supplier for pills in the south, because UK customs does not impound all pharmaceuticals purchased online (although there are periodic crackdowns when abortion pills are seized) (Interviews EU-1 and NI-1). Although the two are separate legal jurisdictions, the open border between Northern Ireland and the Republic means that goods that enter Northern Ireland can be easily moved south, especially small mobile goods like pills. Telemedical services like Women on Web and Women Help Women are therefore able to ship pills into Northern Ireland, from where individuals can collect their pills, activists can bring them across the border, or pills can be repackaged and mailed south in plain packaging (Sheldon 2018). The telemedical services can also make use of a service called Parcel Motel which allows online shoppers to order from UK retailers who do not ship to the Republic of Ireland (Holland 2015). However, this service is known to the authorities and pill packages there are intermittently obstructed by customs (Interview ROI-2). ${ }^{13}$ The irony of this particular north-south route for abortion pills is that Northern Ireland has proven much more willing to criminalize people who order and use abortion pills. Four people in Northern Ireland have been prosecuted for crimes relating to the possession and use of abortion pills (Jelinska and Yanow 2018), while 15-20 people who ordered pills through the post received requests to attend police interviews under caution

${ }^{11}$ For reference, the Health Products Regulatory Agency reports the following (see HPRA 2017, 23):

\begin{tabular}{|l|l|l|}
\hline & $\begin{array}{l}\text { Units of illegal and } \\
\text { falsified medicine } \\
\text { seized (total) }\end{array}$ & $\begin{array}{l}\text { Prosecutions initiated } \\
\text { and voluntary formal } \\
\text { cautions issued (total) }\end{array}$ \\
\hline 2017 & 948,915 & 12 \\
\hline 2016 & 673,906 & 19 \\
\hline 2015 & $1,136,494$ & 19 \\
\hline 2014 & 730,056 & 23 \\
\hline
\end{tabular}

12 The ways in which activists navigated legal ambiguities and regulatory infrastructure to smuggle pills strongly resonates with earlier generations of activists who brought condoms into Ireland from Northern Ireland when they were illegal (Cloatre and Enright 2017).

${ }^{13}$ Interview ROI-2: Activist in an Irish socialist feminist and pro-choice organization, interviewed November 2018. 


\section{S. Calkin}

(Interview NI-1). Others in Northern Ireland have had their homes and offices raided by police bearing search warrants for abortion "equipment" (Interview NI-1; Interview NI-2 ${ }^{14}$ ).

Irish state efforts to intercept and impound illegal abortion pills have been partially successful, although alternative trajectories for pills mean that Irish customs efforts can be avoided by well-organized activists with contacts in neighbouring states and inside Ireland. While it sought to project "official legality" on the surface, the unofficial policy of ignoring and tolerating the majority of clandestine abortion pills inside Ireland reflects what Campbell and Heyman call the "processes of mutual adaptation/ reinforcement/ symbiosis" that often characterize the relationship between states and organizations over the movement of illicit goods (2015: 469). As geographers of the drug trade have noted, efforts to shut down some routes inevitably lead to a 'balloon effect' in which illicit goods re-emerge in other places through smuggling techniques (Taylor et al. 2013). This dynamic is also evident here: far from shutting down demand for EMA, attempts to stop all abortion pills at the border pushed activist networks to develop alternative routes that navigated postal infrastructure and territorial borders to enter the state without being detected. EMA purchased and imported from online pharmacies was continually seized but the best available evidence indicates that customs was able to intercept only a very small portion of abortion pills that entered the country: for example, between 20102012, Women on Web reports it shipped abortion pills to 1,642 women living in Ireland and Northern Ireland ${ }^{15}$ while the Irish medicines agency reported seizing 93 consignments of abortion pills during this same period (Aiken et al. 2016, 4; Sheldon 2016, 92; Ní Aodha 2018). Despite this disparity, the uneasy compromise between abortion-seekers and enforcement agencies signalled a decision by the state to categorize abortion pills as pharmaceutical contraband and an unwillingness to treat imported abortion pills as an attempted violation of its abortion law, as has been the approach elsewhere.

\section{Abortion Pills as a Foreign Health Threat}

Among the illicit flows that transgress political boundaries, biological and chemical elements represent a particularly existential challenge: viruses, microbes, and pathogens are widely

\footnotetext{
${ }^{14}$ Interview NI-2: Activist in a Northern Irish pro-choice organization, interviewed April 2018.

15 This data cannot be disaggregated by the country in which the end-user lives, because as explained above, the pills may have been shipped to an intermediary in Northern Ireland and then moved south by other means, rather than mailed to the end-user's home address (Aiken et al. 2016).
} 


\section{S. Calkin}

understood as threats to the integrity of the state because state borders can never be fully secured against their intrusion (Du Plessis 2018; Fishel 2015). These materials engage in their own bordering practices which bear no allegiance to the political borders that circumscribe state territories. The "unruly mobilities" of pathogens and viruses violate and dissolve established boundaries while governmental responses tend to "conceptually reassert" the primacy of established political scales and the "materiality of bounded nation" (White 2015: 152). The state's toleration for abortion pills, apparent in its unofficial policy of seizure and non-prosecution for abortion pill imports, evidences this relationship. Ireland's abortion ban has been premised on the maintenance of the moral and geographical distinction between "abortion free" Ireland and the prevalence of "Irish abortions" in England. As customs agencies sought to enforce this boundary by seizing illegal pills at the regulatory border, the state agency tasked with public health attempted to maintain this fraught territorial distinction in other ways. As an external matter, it acknowledged but sought to reduce the number of Irish women seeking abortion abroad. As an internal matter, it eventually came to treat the influx of abortion pills as a domestic health risk that could be mitigated by public health interventions.

The main vehicle for public health action on abortion pills in Ireland is the Health Service Executive's Crisis Pregnancy Agency (CPA). ${ }^{16}$ The CPA was established as part of a government strategy to reduce abortion abroad by using domestic governance tools to impact the extra-territorial abortion rate (Fletcher 2013: 167). To this end, the CPA recognized the prevalence of abortion travel out of Ireland, using data from the UK Department of Health to report annually on the number of "Irish abortions" carried out in Britain (Ibid.). It explicitly committed itself to improving the quality of abortion travel from Ireland abroad through campaigns like 'Positive Options' which provided subsidized crisis pregnancy counselling and published informational leaflets for women who had already decided to travel to England for terminations. By contrast, the CPA did not collect data on the small number of legal abortions that occurred in Ireland nor did it offer further clarity on access to legal abortion inside Ireland (Ibid.). The territorial arrangement of Irish abortions, enacted through constitutional amendments to permit abortion travel abroad and information about abortion services abroad, was further institutionalized through state public health programmes to support abortion travel abroad.

\footnotetext{
${ }^{16}$ It was later renamed the Crisis Pregnancy Programme, but for clarity I refer to it throughout as the Crisis Pregnancy Agency.
} 


\section{S. Calkin}

Because part of its mission was to reduce the incidence of Irish women seeking abortion abroad, the Crisis Pregnancy Agency reported declining numbers of abortion travellers as evidence of its success. It attributed the steady drop in abortion travellers from 2001 to its efforts to "lead a coordinated national response to crisis pregnancy prevention and support" (HSE 2011). Assuming that the decline in reported abortion travellers from Ireland could be equated with a straightforward reduction in abortions by Irish women, the CPA claimed that abortion travel numbers have fallen as a result of increased contraceptive use (HSE 2012) and its initiatives which "provide women with the space and time to consider their options" (HSE 2013).

The equation of falling abortion travel numbers with an overall decline in abortion-seekers was steadily undermined by the growth in demand for EMA and increased public attention to EMA. The CPA's reporting on abortion travel numbers first acknowledged the use of "abortion pills" in a footnote to its 2015 press release, in which it emphasized that importing these pills from online pharmacies was illegal and stated the number of pills seized by the customs agency in 2013 (HSE 2015). By 2016, its press release recognized the online demand for EMA but emphasized that travelling abroad for abortion is safer than "ordering the abortion pill online or from other sources and taking it at home alone" (HSE 2016). Its 2017 statement went further by conceding to the prevalence of abortion pills in a way that undermined the CPA's previous claims of success: the CPA cited published studies that used Women on Web's own data about the volume of requests for pills it received from women in Ireland (HSE 2017).

Though the state actors tasked with reducing abortion travel were slow to acknowledge the use of EMA inside Ireland, their main response was to treat abortion pills as a public health issue to be mitigated by harm reduction measures. The CPA's crisis pregnancy websites 'Positive Options' and 'Aftercare.ie' sites both advised women that they could seek confidential medical advice after home use of EMA and they would not be reported to the police (quoted in Sheldon 2018). These sites emphasized the illegal status of abortion pills, their possible side effects and associated health risks, but reassured women that any post-abortion counselling or medical follow up would not be retained in their patient records (see for example Aftercare.ie; 


\section{S. Calkin}

PositiveOptions.ie ${ }^{17}$ ). The CPA's main sexual health web resource offered a list of reasons why Irish women who preferred abortion with pills should travel abroad to access them, stressing the higher quality of care and certainty around the pills when obtained through a clinic (see SexualWellbeing.ie). While recognizing the use of illegal pills, it sought to discourage their import by emphasizing their unknown origins and contents.

State efforts taken to address the use of illegal EMA inside Ireland included public health campaigns, web resources, and public statements that reflected a medical - rather than criminal - orientation to the self-managed abortion. As with the public health interventions studied in the literature on political geographies of disease, state responses are oriented towards reinforcing the symbolic integrity of the border as a dividing line between inside and outside (Du Plessis 2018; Fishel 2015; White 2015). That the virus, or the pill, can easily cross regulatory and political borders exposes their vulnerability. Nonetheless, state responses draw on the idea of the bounded territory and associate threats to it with external actors (Bourne 2011). Ireland's treatment of abortion pills inside the state reflects the importance of this foundational distinction, because its health interventions emphasized the contrast between domestic space (where pills were illegal, dangerous, and unverifiable) and neighbouring jurisdictions (where pills were legal, safe, and accessible with medical oversight). This distinction was maintained through the refusal to license mifepristone in Ireland, even for use in the very small number of legal abortions that took place under the Protection of Life During Pregnancy Act (in force from 2013-2018; see de Londras and Enright 2018). Mifepristone was not licensed for use in Ireland until November 2018, one month before the new abortion law was passed (Shanahan 2018).

\section{Abortion Pills as an Inexorable Digital Flow}

State agencies in Ireland conceptualized abortion pills by analogizing them to familiar crossborder flows, caught between a legal framework that explicitly criminalized the use of such pills and a broader political context in which authorities were unwilling to prosecute individual pill users. For elected politicians, the issue of abortion pills presented a wider crisis of legitimacy because it undermined the uneasy territorial compromise that outsourced Irish

\footnotetext{
${ }^{17}$ After the abortion law changed in January 2019, these websites were taken down. They can still be accessed as cached versions.
} 


\section{S. Calkin}

abortions abroad. Politicians debating the $8^{\text {th }}$ amendment regime during the $2017-2018$ prereferendum process generally acknowledged the obsolescence of the territorial distinction between ostensibly 'abortion-free' Ireland and other jurisdictions. When considering the cause of abortion pill flows, legislators in these debates showed a tendency to externalize the problem by attributing it to the informational and material flows enabled by internet infrastructure, rather than considering the domestic sources of demand for abortion pills. They frequently analogized abortion pills to amorphous online flows, reflecting the broader context in which states conceptualize the internet as a possible vector for the movement of the illicit and still seek to assert control over it (Paasi 2018).

Abortion pills came to the attention of the Irish political establishment when they became a prominent focus of a 2017 parliamentary committee on the $8^{\text {th }}$ amendment, which heard extensive testimony on the illegal use of abortion pills in Ireland (see Aiken 2017). The issue of widespread access to abortion pills became one of two main drivers for the committee's recommendation of allowing abortion on request to 12 weeks (Horgan 2019; Conlon 2017). ${ }^{18}$ Although many reported that they had previously known little or nothing about abortion pills, legislators began to point to their newfound knowledge of abortion pills as a rationale for supporting the reform of abortion laws (see, for example, Murray 2017). When the Oireachtas began to debate the committee report and the reform of the abortion laws in 2017-2018, EMA became a focal point for discussions about the moral, political, and legal legitimacy of the $8^{\text {th }}$ amendment regime. The debate over abortion pills reflected wider debates about the limits of state power in an era of transnational information and material flows, where legitimacy is eroded as its territorial control is challenged.

In the legislative debates, abortion pills became a popular topic for politicians who advanced a reluctant pro-repeal position because they offered a middle ground between the poles of the debate: legislators discussed abortion pills to rhetorically distance themselves from unapologetically pro-choice or categorically anti-abortion views, instead advocating for permissive reforms on a pragmatic basis that centred medical supervision and safety (Calkin 2020). These pragmatic calls to reform the abortion law built on the idea that the state had an obligation to modify and enforce a new set of laws that could reflect the widespread use of

\footnotetext{
${ }^{18}$ The other was committee's decision that it would be practically impossible to legislate for abortion only in cases where the pregnancy resulted from a sexual crime (Conlon 2017).
} 


\section{S. Calkin}

abortion pills, mitigate against the dangers of self-managed abortion outside of medical supervision, and, reimpose democratic control over the availability of abortion. As with reform to Ireland's contraceptive ban during the 1990s, legislative action was partly provoked by recognition that changes in public attitudes and practices made the ban increasingly irrelevant (Enright and Cloatre 2018). The issue of enforcement of the law was key to the debates on abortion reform, as legislators pointed to EMA flows as evidence that the state was practically unable and politically unwilling to enforce its abortion ban:

"I believe very strongly that once the possibility of pharmaceutical termination of pregnancy came about, a totally different situation was created. The State cannot, in fact, prevent it and cannot realistically put people on trial for getting such a tablet online or administering it to themselves" (Senator Michael McDowell, Seanad Debate 03/27/2018).

The futility of guarding the Irish border against abortion pills was explicitly raised in legislative debates, where legislators argued that: "We cannot have a garda [police officer] at every ferry port and airport in Ireland searching" for pills (TD Hildegard Naughton, Dáil Debate 01/17/2018). Similarly, the criminalization of individual pill users was repeatedly raised to demonstrate its absurdity:

"Does any Member of this House seriously suggest that we now set about arresting, prosecuting and jailing all the women who have imported or taken these pills, or those who will take them tomorrow or the day after? Some extremists might favour that course of action. I honestly believe that most Irish people would recoil at the prospect” (TD Brendan Howlin, Dáil Debate 03/20/2018).

The idea that the state's enforcement power was limited in the era of globalized flows was repeatedly referenced in Oireachtas debates on the $8^{\text {th }}$ amendment regime, when legislators argued that the advent of the internet had made the state's abortion ban obsolete and unenforceable. Some anti-abortion politicians employed this analogy to protest the "global interference in our society" that telemedicine abortion networks represented and to lament the state's apparent acquiescence in the face of these threats (TD Kevin O'Keefe, Dáil Debate 03/09/2018; see also Dáil Debate 01/23/2018). By contrast, pro-reform politicians conflated 


\title{
S. Calkin
}

access to abortion pills with access to the internet in order to make the argument that the internet could not be 'shut down' and thus neither could the flow of EMA:

"If we want to become hard line on it, we can say we will ban the Internet, or ban
abortion on the Internet, but reality is reality" (TD Bernard Durkan, Dáil Debate
01/18/2018).

"In the absence of shutting down the Internet, we will never be able to stop women in crisis pregnancies - women who are desperate, alone and afraid - from taking [pills]" (TD Hildegard Naughton, Dáil Debate 01/17/2018).

\begin{abstract}
"Now we have the Internet which did not exist 30 years ago. Kids and young people can go online and purchase abortion pills, unregulated and unethically, which they can use without medical supervision" (Senator Martin Conway, Seanad Debate 03/27/2018).
\end{abstract}

The specific issue of illegal EMA sits in the broader context of anxiety about state sovereignty, national security, and the integrity of the state. Calls to recognize the widespread use of abortion pills demanded pragmatic reforms, but they contained a deeper anxiety about the failure of the legislature to assert its control over this policy area. To conceptualize the kind of threat represented by unrestricted abortion, much of the political discourse sought to bring EMA flows into proximity with familiar geopolitical forces that crossed borders and challenged state authority, arguing for reforms to the abortion law that would bring abortion pills back under state control. Having ruled out the prosecution of individual pill users, as well as the practical possibility of stopping illegal EMA entering the country, political debates centred around the urgent need to establish legal control over EMA, limit its use, and restore legitimacy to the Oireachtas' democratic mandate to regulate abortion inside Ireland.

There is an important corollary to legislative narratives that called for abortion reform in order to restore democratic legitimacy. Legislators who depicted widespread illegal access to abortion pills as a failure of the state to govern also advocated for reform of Ireland's abortion laws as a means to re-impose democratic control and suitable restrictions on abortion access. They centred the ideas of restriction, regulation, and supervision, rather than decisional autonomy of the person seeking an abortion: 
"We do not suggest one should be able to walk into one's local convenience store and purchase an abortion pill as one would a box of Panadol. What is being proposed is highly restricted and regulated and will be carried out in conjunction with the medical profession. Women buy abortion pills online and self-administer them without medical supervision. That is unrestricted.” (TD Lisa Chambers, Dáil Debate 03/20/2018, emphasis added)

TD Chambers' comments demonstrate the rough alignment forged between pro-repeal and antiabortion reasoning in Irish legislative debates. Calling for the repeal of the $8^{\text {th }}$ amendment and legalization of abortion under certain circumstances, she nonetheless portrays mobile as EMA a substance that must be "highly restricted" inside a new spatial arrangement for abortion centred on medical supervision. Medicalized frameworks that legalize abortion under doctors' supervision still serve as a way that state power is "deployed over women" (Sheldon 1997, 3). Indeed, feminist legal scholars have noted that the profound flaws in the new Irish abortion legislation reflect the continuity of the Irish state's pronatalism and paternalism (de Londras 2020; Enright 2019).

\section{Conclusion}

The particularities of abortion pills inside Ireland matter for a wider conversation about power and the state, for three reasons: First, ongoing processes of state re-spatialization, which are usually associated with transformations in the global economy, have profound implications for reproduction. Wider access to reproductive technologies, pharmaceutical products, and information means a re-scaling of reproductive life. This includes familiar activities like travelling abroad for medical services that are illegal in the country of residence - like travel for IVF, commercial surrogacy, or abortion. It also includes less familiar forms of reproductive mobility, like imported abortion pills sent by foreign telemedical services. Second, Political Geographers and International Relations scholars must expand the range of activities we study to see where 'stateness' is performed. The assertion of 'stateness' prominently occurs in the regulation of abortion, especially where restrictions on abortion are justified through nationalist narratives about identity and territory. Imported EMA is changing the ways that women can access abortion and making their ability to end a pregnancy less dependent on the laws of their 


\section{S. Calkin}

home state. Where these trends destabilize familiar forms of control over reproduction, we see varied state responses to impose restrictions. In Ireland, the re-imposition of restrictions on abortion has taken the form of a new law that permits first trimester abortion but situates it inside layers of medical control and gives medical authorities enormous power to obstruct access. Third, the material properties of objects like abortion pills are central to their political power. Because EMA is small and mobile, it moves across borders with relative ease. Following its journey helps us to see the patchy and uneven reality of state control at the border and over the body.

The $8^{\text {th }}$ amendment was repealed in May 2018, clearing the way for new abortion legislation which was passed in December 2018 and came into force in January 2019. The new law permits abortion on request to 12 weeks and in very limited circumstances thereafter (see Enright 2019). This law has decriminalized self-managed abortion, but it maintains a possible 14-year sentence for any doctor or other person who assists someone else to end their pregnancy outside of the terms of the new law (Ibid.). In other words, ordering pills online for yourself is not a crime but helping someone else to get them outside of the formal medical system is still a crime. The demand for abortion pills through online telemedical networks and online pharmacies continues, as does the seizure of these pills by the Irish customs and medicines (O’Regan 2019).

The introduction of a new abortion law in Ireland has served to ease some of the contradictions that crystallized under the $8^{\text {th }}$ amendment, because domestic provision of early termination of pregnancy means that many fewer people travel abroad for abortion. At the same time, the new law has accomplished by symbolic political goal of re-imposing state control over abortion by placing substantial legal and medical barriers on women's ability to access termination of pregnancy. In the political debates leading up to the 2018 referendum, advocates of reform argued that Irish women had grown accustomed to self-managed abortion with pills and would continue to seek out EMA if the new law imposed substantial barriers to access (see Horgan 2019). In the years to come, Ireland's debates over abortion access, reform, and authority will continue to be shaped by abortion pills and their disruptive mobilities. 
S. Calkin

\section{Works Cited}

Abraham, I. and van Schendel, W. 2005. Introduction: The Making of Illicitness. In: van Schendel, W. and Abraham, I. eds. Illicit Flows and Criminal Things: States, Borders, and the Other Side of Globalization. Indiana University Press, pp. 1-37.

Aiken, A. R., Gomperts, R. and Trussell, J., 2017. Experiences and characteristics of women seeking and completing at- home medical termination of pregnancy through online telemedicine in Ireland and Northern Ireland: a population- based analysis. BJOG: An International Journal of Obstetrics \& Gynaecology, 124(8), pp.1208-1215.

Aiken, A.R. 2017. Opening Statement to the Joint Oireachtas Committee on the Eighth Amendment to the Constitution. 11 October, 2017. Available at <Oireachtas.ie>

Aiken, A.R. et al. 2017. Experiences and characteristics of women seeking and completing athome medical termination of pregnancy through online telemedicine in Ireland and Northern Ireland: a population-based analysis. BJOG: An International Journal of Obstetrics \& Gynaecology 124(8), pp. 1208-1215.

Amoore, L. 2006. Biometric borders: Governing mobilities in the war on terror. Political Geography 25(3), pp. 336-351.

Baird, B. 2015. Medical abortion in Australia: a short history. Reproductive Health Matters 23(46), pp. 169-176.

Banister, J. M., Boyce, G. A., \& Slack, J. (2015). Illicit economies and state (less) geographies: The politics of illegality. Territory, Politics, Governance 3(4), pp.365-368.

Barot, Sneha. 2018. The Roadmap to Safe Abortion Worldwide: Lessons from New Global Trends on Incidence, Legality and Safety. Guttmacher Policy Review. Vol. 21. Pp.17-22.

Blumenthal, et al. 2009. Providing medical abortion in low-resource settings: an introductory guidebook. Gynuity Health Projects. New York, New York. Second edition. Available at https://gynuity.org/resources/medical-abortion-guidebook

Bourne, M. 2011. Netwar Geopolitics: Security, Failed States and Illicit Flows. The British Journal of Politics and International Relations 13(4), pp. 490-513.

Bourne, M. 2015. Cocaine. In: Salter, M. B. ed. Making Things International 1: Circuits and Motion. Univ Of Minnesota Press

Braun, B. and Whatmore, S. 2010. Political Matter: Technoscience, Democracy, and Public Life. Univ of Minnesota Press.

Browne, K. and Nash, C.J. Forthcoming, 2020. Love Both: Heteroactivism and 'Pro-Life' Posters in Ireland's 8th Referendum. Feminist Review 24. Ahead of print. 
S. Calkin

Calkin, S. 2019a. Towards a political geography of abortion. Political Geography 69, pp. 2229.

Calkin, S. 2019b. Healthcare, Not Airfare! Art, Abortion and Political Agency in Ireland. Gender, Place \& Culture. 26(3), pp.338-361.

Calkin, S. Forthcoming, 2020. Abortion pills in Ireland and beyond: what can the 8th amendment referendum tell us about the future of self-managed abortion? in After Repeal: Rethinking Abortion Politics, Eds. K. Browne and S. Calkin (pp.73-89).

Campbell, P. 2018. Making sense of the abortion pill: a sociotechnical analysis of RU486 in Canada. Health Sociology Review 27(2), pp. 121-135.

Campbell, H., \& Heyman, J. M. 2015. Illicit economies and state (less) geographies-The politics of illegality: A commentary by Howard Campbell and Josiah Heyman. Territory, Politics, Governance, 3(4), pp.469-472.

Clarke, A. and Montini, T. 1993. The Many Faces of RU486: Tales of Situated Knowledges and Technological Contestations. Science, Technology, \& Human Values 18(1), pp. 4278.

Cloatre, E. and Enright, M., 2017. 'On the Perimeter of the Lawful': Enduring Illegality in the Irish Family Planning Movement, 1972-1985. Journal of law and society, 44(4), pp.471500.

Conlon, D. 2017. 'Huge lack of understanding' of abortion in Oireachtas. Available at: https://www.irishtimes.com/news/politics/huge-lack-of-understanding-of-abortion-inoireachtas-1.3334074.

Connolly, L. 2001. The Irish women's movement: From revolution to devolution. Springer.

Connolly, L. Forthcoming, 2020. How did repeal happen? A long term view. After Repeal, eds. K. Browne and S. Calkin. London: Zed Books.

Cowen, D. 2014. The Deadly Life of Logistics: Mapping Violence in Global Trade. Univ of Minnesota Press.

Drovetta, R.I. 2015. Safe abortion information hotlines: An effective strategy for increasing women's access to safe abortions in Latin America. Reproductive Health Matters 23(45), pp. 47-57.

Enright, M. 2019. Abortion law in Ireland: Reflecting on reform. In: Black, L. and Dunne, P. eds. Law and Gender in Modern Ireland: Critique and Reform. Hart Publishing, pp. 5570.

Enright, M. and Cloatre, E. 2018. Transformative Illegality: How Condoms 'Became Legal' in Ireland, 1991-1993. Feminist Legal Studies 26(3), pp. 261-284. 
S. Calkin

Fishel, S. 2015. Microbes. In: Salter, M. B. ed. Making Things International 1: Circuits and Motion. Univ Of Minnesota Press.

Fletcher, R. 2001. Post- colonial fragments: Representations of abortion in Irish law and politics. Journal of Law and Society 28(4), pp. 568-579.

Fletcher, R. 2005. Reproducing Irishness: Race, gender, and abortion law. Canadian Journal of Women and the Law 17(2), pp. 365-404.

Fletcher, R. 2013. Peripheral governance: administering transnational health-care flows. International Journal of Law in Context 9(2), pp. 160-191.

Ganatra, B. et al. 2017. Global, regional, and subregional classification of abortions by safety, 2010-14: estimates from a Bayesian hierarchical model. The Lancet. 390: 10110, P23722381

Gilmartin, M. and Kennedy, S. 2018. Mobility, migrants and abortion in Ireland. In: Crossing Troubled Waters: Abortion in Ireland, Northern Ireland, and Prince Edward Island. Island Studies Press, pp. 138-60.

Gregson, N. and Crang, M. 2017. Illicit economies: customary illegality, moral economies and circulation. Transactions of the Institute of British Geographers 42(2), pp. 206-219.

Gynuity Health Projects. 2017. Map of Mifepristone Approvals. Gynuity Health Projects [Website]. Last updated June 1, 2017. Available at https://gynuity.org/resources/map-of$\underline{\text { mifepristone-approvals }}$

Health Products Regulatory Authority. 2015. Annual Report 2015. Available at: https://www.hpra.ie/docs/default-source/publications-forms/corporate-policydocuments/hpra-annual-report-2015.pdf?sfvrsn=11

Health Products Regulatory Authority. 2016. Annual Report 2016. Available at: https://www.hpra.ie/docs/default-source/publications-forms/corporate-policydocuments/hpra-annual-report-2016.pdf?sfvrsn=6

Health Products Regulatory Authority. 2017. Annual Report 2017. Available at: https://www.hpra.ie/docs/default-source/publications-forms/corporate-policydocuments/annual-report-2017.pdf?sfvrsn=4

Health Services Executive 2011. Number of Women Giving Irish Addresses at UK Abortion Clinics Decreases for Ninth Year in a Row. Available at: https://www.hse.ie/eng/services/news/media/pressrel/newsarchive/2011archive/may201 1/womenirishaddressukabortionclinicsdecreases.html.

Health Services Executive 2012. Number of Women Giving Irish Addresses at UK Abortion Clinics Decreases for Tenth Year in a Row According to Department of Health UK. 
S. Calkin

Available

at:

https://www.hse.ie/eng/services/news/media/pressrel/newsarchive/2012archive/may201 2archive/abortionclinics.html.

Health Services Executive 2013. Number of women giving Irish addresses at UK Abortion Clinics decreases.

Available

at: https://www.hse.ie/eng/services/news/media/pressrel/newsarchive/2013archive/july201 3/ukabortionclinics.html.

Health Services Executive 2015. Number of Women Giving Irish Addresses at Abortion Clinics in 2014. Available at: https://www.hse.ie/eng/services/news/media/pressrel/newsarchive/archive15/jun15/uka bortionfigures.html.

Health Services Executive 2016. UK records show decrease in women giving Irish addresses at abortion clinics. Available at: https://www.hse.ie/eng/services/news/media/pressrel/crisispregprog.html.

Health Services Executive 2017. Over 50\% decrease in the number of women giving Irish addresses at abortion clinics in England and Wales. Available at: https://www.hse.ie/eng/services/news/media/pressrel/over-50-decrease-in-the-numberof-women-giving-irish-addresses-at-abortion-clinics-in-england-andwales $\% \mathrm{E} 2 \% 80 \% \mathrm{~A} 6$.

Holland, K. 2015. Emily's story: An illegal abortion in Ireland. Available at: https://www.irishtimes.com/life-and-style/people/emily-s-story-an-illegal-abortion-inireland-1.2376568.

Horgan, G. 2019. The Genie is out of the Bottle: Self-managed abortions in Northern Ireland Using Pills. Access Research Knowledge. ARK Research Update 127, March 2019. https://www.ark.ac.uk/ARK/sites/default/files/2019-03/update127.pdf

Irish Family Planning Association 2018. Abortion in Ireland: Statistics. Available at: https://www.ifpa.ie/Hot-Topics/Abortion/Statistics.

Jelinska, K. and Yanow, S. 2018. Putting abortion pills into women's hands: realizing the full potential of medical abortion. Contraception 97(2), pp. 86-89.

Joffe, C. and Weitz, T.A. 2003. Normalizing the exceptional: incorporating the "abortion pill" into mainstream medicine. Social Science \& Medicine 56(12), pp. 2353-2366.

de Londras, F. and Enright, M. 2018. Repealing the 8th: Reforming Irish Abortion Law. Policy Press.

Luibhéid, E. 2013. Pregnant on Arrival. University of Minnesota Press. 
S. Calkin

Murphy, B. 2016. Deadly haul of 'online drugs' seized in five locations around Ireland. The Irish Mirror 9 June, 2016. Available at: http://www.irishmirror.ie/news/abortion-pillssedatives-steroids-painkillers-8148874.

Murray, S. 2017. Why this pro-life TD is calling for regulated access to abortion pill. Available at: $\quad$ https://www.independent.ie/irish-news/politics/why-this-prolife-td-is-calling-forregulated-access-to-abortion-pill-36400233.html.

Ni Aodha, G. 2018. 'Here's the number of abortion pills seized in Ireland in the past 10 years.' TheJournal.ie. 3 April 2018. https://www.thejournal.ie/abortion-pill-use-in-ireland$\underline{3892752-A p r 2018 /}$

O'Regan, E. 2019. 'Abortion pills still illegally imported despite change in law.' The Irish Independent. 11 June 2019. https://www.independent.ie/irish-news/health/abortionpills-still-illegally-imported-despite-change-in-law-38202080.html

Paasi, A. 2018. Borderless worlds and beyond: challenging the state-centric cartographies. In: Prokkola, E.-K. et al. eds. Borderless Worlds for Whom?: Ethics, Moralities and Mobilities. Routledge, pp. 21-36.

Painter, J. 2006. Prosaic geographies of stateness. Political Geography 25(7), pp.752-774.

du Plessis, G. 2018. When pathogens determine the territory: Toward a concept of non-human borders. European Journal of International Relations 24(2), pp. 391-413.

Quet, M. 2018. Pharmaceutical Capitalism and its Logistics: Access to Hepatitis C Treatment. Theory, Culture \& Society 35(2), pp. 67-89.

Rossiter, A. 2009. Ireland's Hidden Diaspora: the 'abortion trail' and the making of a LondonIrish underground, 1980-2000. IASC Press.

Ryan, C. 2011. Abortion by Post. The Irish Times 15 March. Available at: https://www.irishtimes.com/news/health/abortion-by-post-1.573017.

Salter, M.B. ed. 2015. Making Things International 1: Circuits and Motion. Univ Of Minnesota Press.

Salter, M.B. ed. 2016. Making Things International 2: Catalysts and Reactions. Univ Of Minnesota Press.

Sassen, S. 2013. When Territory Deborders Territoriality. Territory, Politics, Governance 1(1), pp. $21-45$.

van Schendel, W. et al. eds. 2005. Spaces of Engagement: How Borderlands, Illicit Flows and Territorial States Interlock. In: Illicit Flows and Criminal Things: States, Borders, and the Other Side of Globalization. Indiana University Press, pp. 38-68. 
S. Calkin

van Schendel, W. and Abraham, I. 2005. Illicit Flows and Criminal Things: States, Borders, and the Other Side of Globalization. Indiana University Press.

Shanahan, C. 2018. Abortion pill approved for the first time. The Irish Examiner 4 December. Available at: https://www.irishexaminer.com/breakingnews/ireland/abortion-pillapproved-for-the-first-time-889664.html.

Sheldon, S. 1997. Beyond control: medical power and abortion law. Pluto Press.

Sheldon, S. 2014. The Medical Framework and Early Medical Abortion in the U.K.: How Can a State Control Swallowing? In: Cook, R. et al. eds. Abortion Law in Transnational Perspective : Cases and Controversies. University of Pennsylvania Press, pp. 189-209.

Sheldon, S., 2016. How can a state control swallowing? The home use of abortion pills in Ireland. Reproductive health matters, 24(48), pp.90-101.

Sheldon, S. 2018. Empowerment and Privacy? Home Use of Abortion Pills in the Republic of Ireland. Signs 43(4), pp. 823-849.

Smyth, L. 2005. Abortion and Nation: The Politics of Reproduction in Contemporary Ireland. Abingdon: Routledge.

Taylor, J. S., Jasparro, C., \& Mattson, K. 2013. Geographers and drugs: A survey of the literature. Geographical Review, 103(3), pp.415-430.

Whitaker, R. and Horgan, G. 2016. Abortion Governance in the New Northern Ireland. In: Zordo, S. D. et al. eds. A Fragmented Landscape: Abortion Governance and Protest Logics in Europe. Berghahn Books

White, M. 2015. Virus. In: Salter, M. B. ed. Making Things International 1: Circuits and Motion. Univ Of Minnesota Press.

Women Help Women 2018. In solidarity with Repeal the 8th! Referendum in Ireland on May 25th! 10 April. Available at: https://womenhelp.org/en/page/900/in-solidarity-withrepeal-the-8th-referendum-in-ireland-on-may-25th.

de Zordo, S. 2016. The biomedicalisation of illegal abortion: the double life of misoprostol in Brazil. História, Ciências, Saúde-Manguinhos 23(1), pp. 19-36. 